УДК 615.014.47 (091)

DOI https://doi.org/10.11603/2312-0967.2020.4.11642

\title{
ОЦІНКА ЕФЕКТИВНОСТІ БОРОТЬБИ 3 ФАЛЬСИФІКАЦІЕЮ ЛІКАРСЬКИХ ЗАСОБІВ В УКРАЇНІ: ПОГЛЯД ФАХІВЦІВ АПТЕЧНИХ ЗАКЛАДІВ
}

\author{
С. О. Лебедь ${ }^{1}$, А. С. Немченко ${ }^{1}$, М. Ф. Пасічник ${ }^{2}$ \\ Національний фрармацевтичний університет ${ }^{1}$, Харків \\ Громадська спілка «Фармацевтична Ліга України» ${ }^{2}$, Київ \\ economica@ukr.net
}

ІНФОРМАЦІЯ

Надійшла до редакції / Received: 20.10 .2020

Після доопрацювання / Revised: 04.11 .2020

Прийнято до друку / Accepted: 10.11.2020

\section{Ключові слова:}

ліки;

фральсифрікація;

фральсифріковані лікарські засоби; аптечні заклади;

фрармацевтичні фрахівці;

анкетування;

респонденти.
АНОТАЦІЯ

Мета роботи. Проведення оцінки ефективності боротьби з фральсифрікацією ліків із використанням анкетного опитування фрахівців аптечних закладів різних регіонів України.

Матеріали і методи. Наукові публікації за проблемою фральсифрікації ліків, а також аналіз даних анкетування фрахівців аптечних закладів різних регіонів України щодо проблем боротьби з фральсисрікацією лікарських засобів (ЛЗ). Дослідження проводили з використанням методів анкетного опитування, систематизації та узагальнення.

Результати й обговорення. За результатами анкетного опитування, проведеного на національному рівні (13 областей, що представляють схід, захід, північ, південь та центр України), понад 33 \% опитуваних відповіли, що частка фральсифрікованих лікарських засобів (ФЛЗ) складає від 1 до 5 \%, що відповідає даним, які наводила ВООЗ щодо об'єму субстандартних та фальсифрікованих лікарських засобів для країн з низьким і середнім рівнем доходу (до 10,5 \%) [1]. До ознак фральсифрікації Л3 респонденти найбільше віднесли «Маркування на іноземній мові» (44,85 \%). Щодо основних каналів збуту ФЛЗ, то понад 75 \% респондентів назвали інтернет-торгівлю. Стосовно методів та заходів, які слід застосовувати виробникам та аптечним закладам у боротьбі з фальсифрікацією ліків, то такими назвали дотримання стандарту GMP близько 75 \% опитуваних, в той же час понад $64 \%$ очікують від виробників запровадження додаткового захисту упаковок лЗ від підробок, зокрема 44 \% - обов'язковий перехід на маркування 2-d штрих-кодами, а також понад 78 \% респондентів назвали закупівлю ЛЗ лише у постачальників, сертисрікованих на відповідність GDP.

Висновки. 3 метою створення ефективної системи боротьби 3 розповсюдженням фральсифрікованих ліків запропоновано створення Національної програми боротьби з фральсифрікацією Л3, а також розробка практичних рекомендацій для фрармацевтичних фрахівців щодо виявлення фальсифікованих препаратів і запобігання їх незаконному обігу.
Вступ. До двох мільярдів людей у всьому світі не мають належного доступу до необхідних ліків, вакцин, медичних виробів, включно діагностику in vitro та інших товарів аптечного асортименту, що створює вакуум, який занадто часто заповнюють неякісні та фральсифіковані продукти. Ця проблема зростає в

ISSN 2312-0967. Фармацевтичний часопис. 2020. № 4 
міру ускладнення глобальних ланцюгів поставок, тобто медична продукція, вироблена в одній країні, може бути упакована в іншій країні та розповсюджена через кордони для продажу споживачам у третій. Зростання електронної торгівлі також сприяє цій тенденції, полегшуючи придбання ліків через Інтернет, часто з несанкціонованих джерел. Всесвітня організація охорони здоров'я (ВОО3) визначила це питання однією 3 нагальних проблем медицини та фрармації на наступне десятиліття, враховуючи, що більш ніж кожен десятий Лз у країнах із низьким та середнім рівнем доходу вважається неякісним або фральсиорікованим. Жодна країна не залишається осторонь цих питань, тому ВООЗ отримує повідомлення про неякісні або ФЛЗ, вакцини та діагностичні засоби з усіх регіонів світу. Як генеричні, так і інноваційні ліки можна фральсифікувати: від дуже дорогих протипухлинних препаратів і до недорогих знеболювальних [2]. Не оминула ця проблема і Україну. Впродовж останніх 10 років Державною службою 3 лікарських засобів та контролю за наркотиками (Держлікслужба) видано 440 розпоряджень про заборону обігу фальсифрікованих лікарських засобів, у тому числі 25 розпоряджень видано у 2019-2020 рр. (станом на жовтень 2020 року). У публікаціях [3, 4] ми розглянули експертну оцінку ефективності боротьби з фальсифрікацією лікарських засобів фрахівців Держлікслужби та її територіальних підрозділів.

Мета роботи - проведення оцінки ефективності боротьби з фальсифрікацією ліків із використанням анкетного опитування фрахівців аптечних закладів різних регіонів України.

Матеріали і методи. Об'єктом дослідження стали наукові публікації, а також аналіз даних анкетування срахівців аптечних закладів різних регіонів України щодо проблем боротьби 3 фральсифрікацією лікарських засобів. Дослідження проводили з використанням методів анкетного опитування, систематизації та узагальнення.

Результати й обговорення. Упродовж 20192020 рр. у Національному фармацевтичному університеті на національному рівні було проведено анкетне опитування 3 метою вивчення думок фрахівців суб'єктів господарювання, аптечні заклади яких розташовані в 13 регіонах України щодо оцінки ефективності боротьби з розповсюдженням ФЛз в Україні, а також напрямків з удосконалення методів їхнього виявлення.

Подібні пілотні опитування щодо проблем фальсифрікації ЛЗ та обізнаності з ними медичних та фрармацевтичних фрахівців було проведено в Казахстані [5], Астраханській області та Республіці Татарстан Російської Федерації [6], Великобританії [7] та Болгарії [8]. Також подібні опитування серед фрармацевтів проводили в аптеках Харкова щодо проблем вхідного контролю якості лікарських засобів [9].

Проведення відбору респондентів здійснювали на основі цілеспрямованого їхнього вибору з урахуван- ням таких основних засад: високий освітньо-квалісрікаційний рівень та наявність певного професійного стажу роботи таких фрахівців.

В опитуванні брали участь 437 респондентів-орармацевтів та провізорів аптечних закладів різних регіонів (13 областей, що представляють схід, захід, північ, південь та центр України) та різних фрорм власності (табл.).

Як бачимо, понад 51 \% опитуваних мають рівень освіти не нижче провізора, понад 65 \% мають кваліфрікаційну категорію не нижче другої, стаж роботи у фармацевтичній галузі більше 10 років мають понад 64 \% опитуваних. Понад 53 \% опитуваних працюють на керівних посадах (завідувачів аптек, завідувачів аптечних пунктів), що підтверджує високий освітньокваліфрікаційний рівень, необхідний професійний стаж роботи та компетенцію. Аналіз наукових публікацій та практичний досвід із досліджуваної проблематики дав нам змогу розробити анкету, яка традиційно включала дані про респондентів, а також 17 запитань за двома розділами щодо оцінки стану та проблем боротьби з розповсюдженням ФЛЗ. Респондентам пропонувалось, залежно від запитань, від 3 до 11 варіантів відповідей, а також були передбачені варіанти - інша відповідь чи вагаюсь відповісти. Анкетування проводили шляхом особистого письмового опитування фармацевтичних фрахівців.

До ключових завдань проведеного нами опитування, на нашу думку, слід віднести оцінку рівня проблеми та визначення найефективніших напрямків та методів, які слід застосовувати для виявлення фральсифрікованих ліків.

На запитання «Яка на Вашу думку частка ФЛЗ на орармацевтичному ринку України?» понад 33 \% опитуваних відповіли, що частка фальсифрікованих ліків складає від 1 до 5 \%, ще $23 \%$ відповіли, що частка фральсифрікату складає від 5 до 10 \%, і тільки 3,43 \% назвали частку ФЛЗ на рівні понад 50 \% (рис. 1).

Як відомо, Держлікслужбою України повідомлялося про інші дані щодо частки виявлених фральсифікованих ліків на ринку України, зокрема - у 2015 році 0,12 \%; у 2016 році - 0,12 \%; у 2017 році - 0,004\% [10], що може свідчити про те, що оцінка фрахівців аптечних закладів щодо обсягів фральсифікованих ЛЗ грунтується на засиллі некоректної інформації від некомпетентних політиків та чиновників, а також на недостатньому інсрормуванні населення з вказаних питань уповноваженими органами.

Особливу актуальність в опитуванні мало питання щодо визначення ознак фральсифрікованих ЛЗ під час надходження їх в аптечні заклади, оскільки на етапі вхідного контролю $є$ можливість виявити ФЛЗ та не допустити їхню подальшу реалізацію. Одержані результати подано на рисунку 2. Як бачимо, до ознак фральсифрікації ліків респонденти найбільше віднесли «Маркування на іноземній мові» $(44,85$ \%), «Помилки в тексті маркування упаковки або сертифікату серії,

ISSN 2312-0967. Pharmaceutical review. 2020. № 4 
Організація роботи аптечних підприємств

Organization of pharmaceutical structures' work

\section{Таблиця}

Аналіз показників, що характеризують респондентів

\begin{tabular}{|c|c|}
\hline \multicolumn{2}{|c|}{ Освіта та кваліфрікаційний рівень } \\
\hline Провізор, магістр (спеціаліст) & $51,03 \%$ \\
\hline Фармацевт, бакалавр & $17,85 \%$ \\
\hline Фармацевт, молодший спеціаліст & $31,12 \%$ \\
\hline \multicolumn{2}{|l|}{ Kamezopiï: } \\
\hline 1) вища категорія & $34,09 \%$ \\
\hline 2) перша категорія & $15,53 \%$ \\
\hline 3) друга категорія & $15,53 \%$ \\
\hline 4) немає категорії & $34,85 \%$ \\
\hline \multicolumn{2}{|c|}{ Стаж роботи на посадах в аптечних закладах } \\
\hline до 1 року & $3,43 \%$ \\
\hline від 1 до 3 років & $9,15 \%$ \\
\hline від 3 до 5 років & $9,38 \%$ \\
\hline від 5 до 10 років & $13,96 \%$ \\
\hline від 10 до 15 років & $15,79 \%$ \\
\hline понад 15 років & $13,50 \%$ \\
\hline понад 20 років & $34,78 \%$ \\
\hline \multicolumn{2}{|c|}{ Посада } \\
\hline Завідувач аптеки & $14,19 \%$ \\
\hline Завідувач аптеки, уповноважена особа & $15,79 \%$ \\
\hline Фармацевт, завідувач аптеки & $20,59 \%$ \\
\hline Фармацевт, завідувач аптечного пункту & $3,20 \%$ \\
\hline Провізор & $40,96 \%$ \\
\hline Фармацевт & $1,60 \%$ \\
\hline Інше & $3,66 \%$ \\
\hline \multicolumn{2}{|l|}{ Характеристика аптечного заклада } \\
\hline Аптека належить фрізичній особі-підприємцю & $15,10 \%$ \\
\hline Аптека належить невеликій компанії (до 20 закладів) & $37,99 \%$ \\
\hline Аптека належить до мережевої (понад 20 закладів) & $46,91 \%$ \\
\hline
\end{tabular}

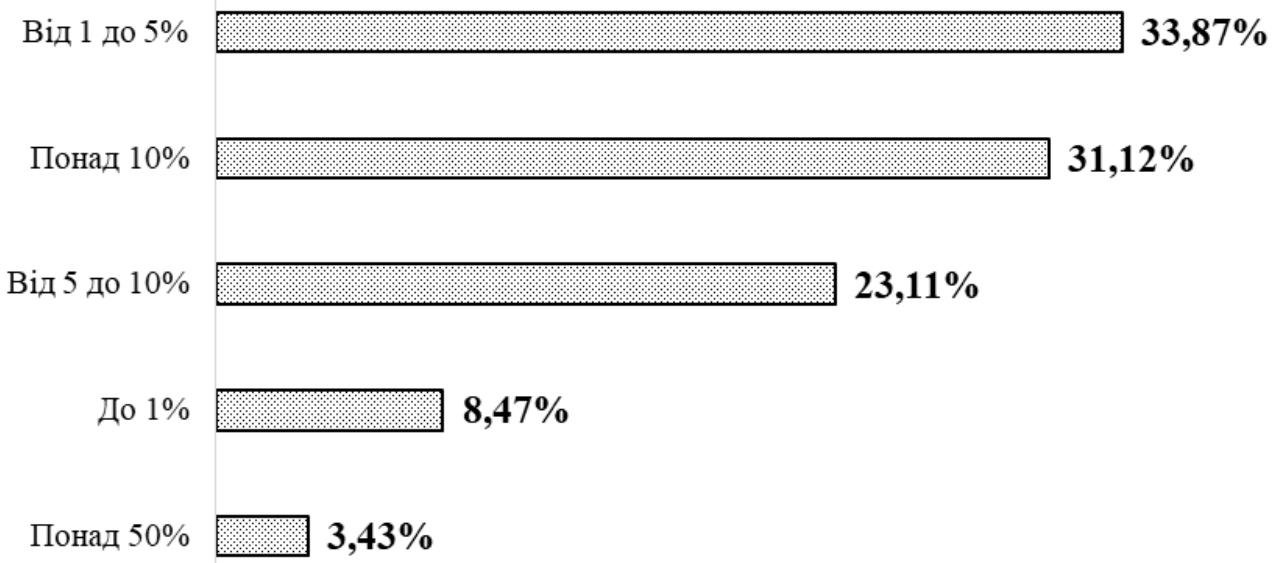

Рис. 1. Частка фральсифрікованих лікарських засобів на фрармацевтичному ринку України, на думку опитуваних фрахівців аптечних закладів.

ISSN 2312-0967. Фармацевтичний часопис. 2020. № 4 
Організація роботи аптечних підприемств Organization of pharmaceutical structures' work

що видається виробником» (43,02\%) та «Ціна, яка суттєво нижча, ніж зазвичай» $(41,42 \%)$. «Відсутність терапевтичного ефректу» як ознаку фральсифікації ЛЗ визначили лише 0,46 \% респондентів, що свідчить, на нашу думку, про низький відсоток звернень споживачів саме до аптечних закладів із цією проблемою.

На наступному етапі досліджень ми оцінювали думку срармацевтичних фрахівців щодо основних каналів збуту ФЛз: понад 75 \% респондентів назвали інтернет-торгівлю, більш ніж 13 \% - аптечну мережу, 9,61 \% - інші заклади торгівлі (крім аптечних). Результати опитування фрахівців аптечних закладів представлено на рисунку 3.

На нашу думку, заслуговують на увагу оцінки респондентів стосовно фракторів, які сприяють фральсифрікації Лз в Україні. На неконтрольовану інтернетторгівлю ЛЗ як фрактор, що сприяє ФЛЗ, вказали понад 73 \% опитуваних.

Маркування на іноземній мові

Помилки в тексті маркування упаковки або сертифікату серії, що видається виробником

Ціна (суттєво нижча, ніж зазвичай)

Зміна звичайних ознак (смак, запах, колір)

Етикетка (інакша, ніж завжди)

Відсутність шрифту Брайля

Відсутність голограми

Вагаюсь відповісти

(1)

Відсутність терапевтичного ефекту ще близько 40 \% респондентів ключовими фракторами назвали неефективну систему заходів державного нагляду (контролю) та м'якість покарання осіб, винних за фральсифрікацію ЛЗ. Понад 30 \% респондентів до таких фракторів віднесли безвідповідальне самолікування населення та неефективну роботу правоохоронних органів (рис. 4).

Окремим етапом дослідження було опитування, щоб оцінити думку фрахівців аптечних закладів щодо методів, які слід застосовувати для виявлення ФЛЗ, під час роздрібної торгівлі, та заходи, які необхідно вживати виробникам ліків для захисту від фральсифікації своєї продукції (рис. 5, 6). Роботу аптечних закладів по «закупівлі ЛЗ лише у перевірених постачальників, сертифікованих на відповідність GDP» назвали більшість опитуваних - понад 78 \%. Близько $40 \%$ респондентів ефективними методами виявлення ФЛЗ назвали «уважний візуальний огляд

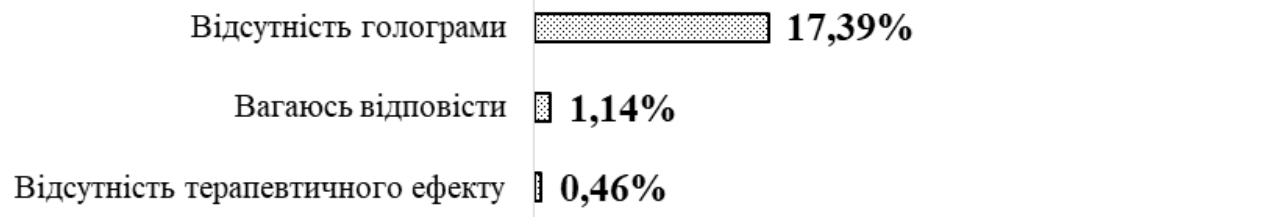

Рис. 2. Ознаки фральсифікованих лікарських засобів, на думку опитуваних фрахівців аптечних закладів.

Інтернет-торгівля

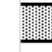

Аптечна мережа

Інші заклади торгівлі (крім аптечних)

Вагаюсь відповісти

Безпосередньо лікарі (під час прийому хворих)

Iнше $\mid \mathbf{0 , 4 6 \%}$

\section{$13,27 \%$}

$9,61 \%$

\section{$4,58 \%$}

$3,20 \%$

\section{$30,66 \%$}

$44,85 \%$

$43,02 \%$

$41,42 \%$

$22,20 \%$

$19,45 \%$

\section{$17,39 \%$}

$75,74 \%$

Рис. 3. Основні канали збуту фральсифрікованих лікарських засобів, на думку опитуваних фрахівців аптечних закладів.

ISSN 2312-0967. Pharmaceutical review. 2020. № 4 


\section{$73,46 \%$}

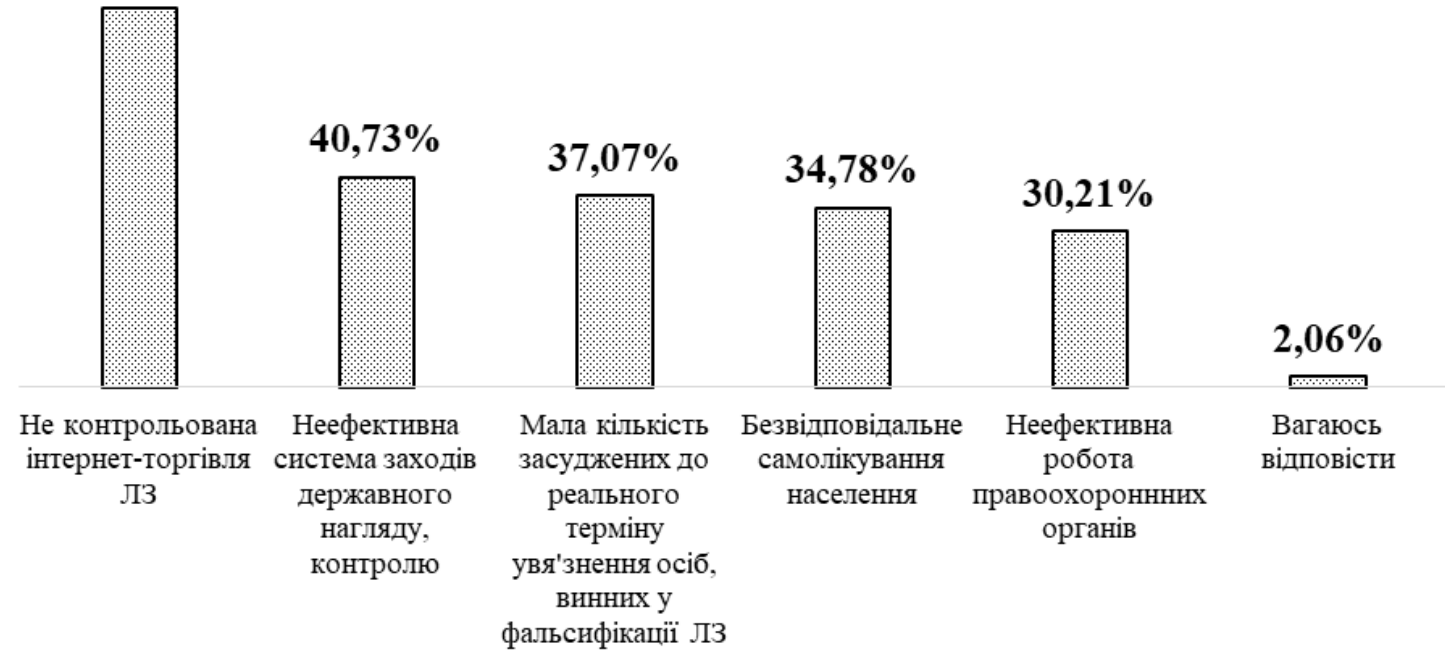

Рис. 4. Фактори, які сприяють фральсифрікації ліків в Україні, на думку опитуваних фрахівців аптечних закладів.

упаковок ЛЗ» при вхідному контролі та «можливість сканування в аптеці 2-d штрих-кодів за допомогою спеціального обладнання та програмного забезпечення», ще 33 \% опитуваних назвали «детальне вивчення супровідних документів», а понад $14 \%$ - «використання експрес-методів контролю якості Лз безпосередньо в аптеках».

Неухильно дотримуватися стандарту GMP при виробництві ЛЗ очікують від виробників близько $75 \%$ опитуваних фрахівців аптечних закладів. Водночас понад 64 \% опитуваних очікують від виробників запровадження додаткових елементів захисту упаковок Л3 від підробок, ще 44 \% - обов'язковий перехід на маркування 2-d штрих-кодами.

Працювати лише 3 перевіреними постачальниками, які мають сертифікат GDP

Уважний візуальний огляд упаковок

Сканування 2-d штрих-кодів за допомогою соціального обладнання та програмного забезпечення

Детальне вивчення супровідних документів

Використання експрес-методів контролю якості Л3 безпосередньо в аптеках

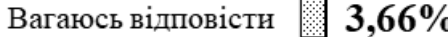

$$
\begin{aligned}
& \text { Інше | } 0,23 \%
\end{aligned}
$$

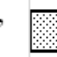

На нашу думку, слід також звернути увагу, що майже 20 \% респондентів очікують від виробників лікарських препаратів активного залучення медичних представників фрармацевтичних фрірм до виявлення ФЛ3, адже вони якнайкраще знають особливості дизайну упаковок, шляхів дистрибуції, об'ємів реалізації тощо. Цю ж тезу підтверджує наступне опитування щодо додаткових заходів запровадження яких безпосередньо в аптечних закладах, дозволить виявляти ФЛЗ та не допускати їхній відпуск. Понад 25 \% респондентів вважають, що медичні представники мають активно проводити інформаційну роботу щодо фральсифрікації ліків. Також більш ніж 70 \% опитуваних вважають, що додатковим заходом протидії $78,49 \%$

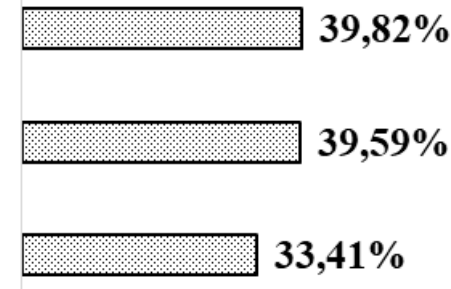

$14,42 \%$

Рис. 5. Які методи слід застосовувати для виявлення фральсифрікованих лікарських засобів під час роздрібної торгівлі?

ISSN 2312-0967. Фармацевтичний часопис. 2020. № 4 


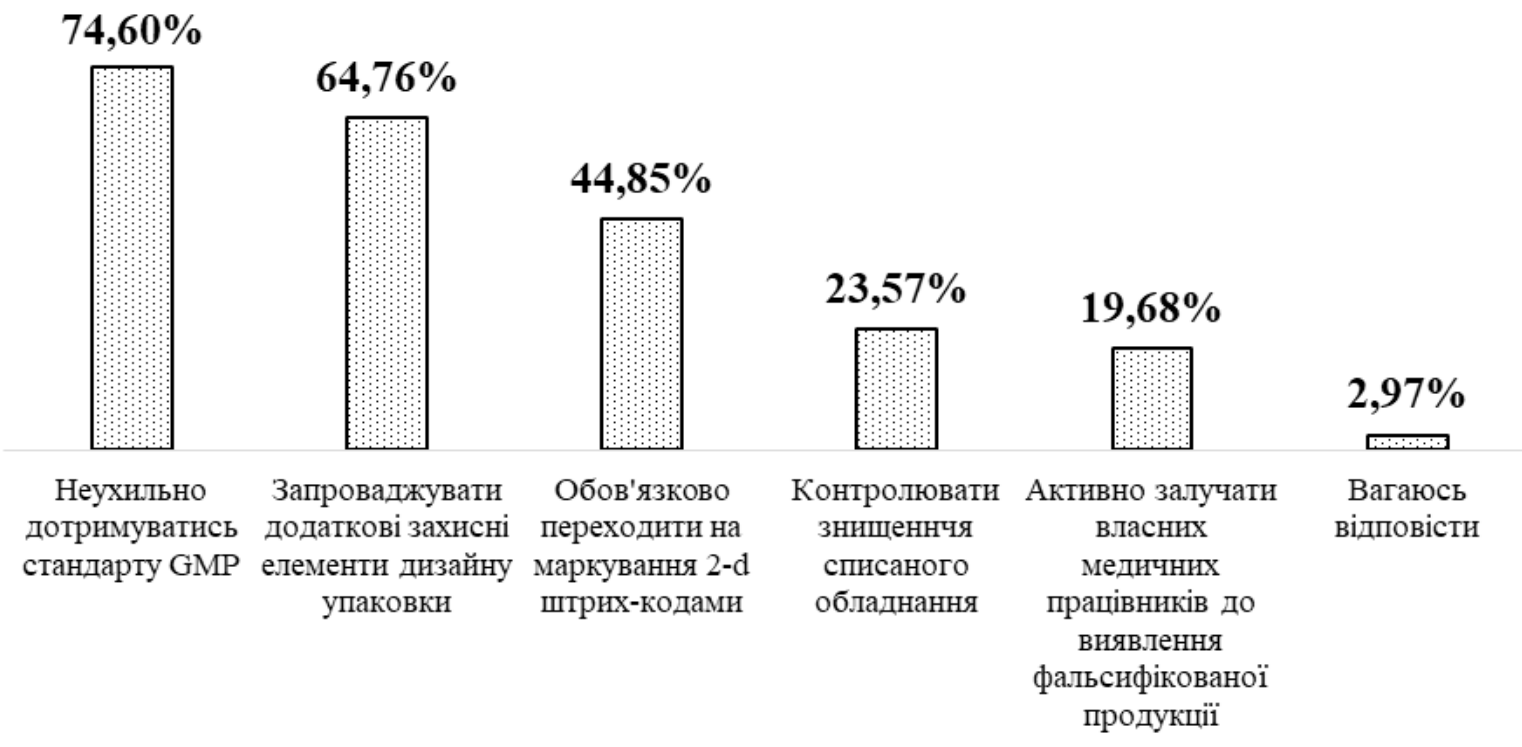

Рис. 6. Заходи, які необхідно застосовувати виробникам ліків для захисту від фральсифікації продукції, на думку опитуваних фрахівців аптечних закладів.

фральсисрікації ліків може бути посерійний контроль якості всіх вироблених та ввезених препаратів у незалежних лабораторіях на етапі оптової торгівлі, понад 52 \% вважають, що аптека повинна мати право безкоштовно перевірити якість сумнівних ліків. Слід зазначити, що це питання дискусійне, оскільки посерійний контроль на стадії кінцевої реалізації ліків споживачам - задоволення не з дешевих і навряд чи есрективне. Якість препаратів необхідно забезпечувати передусім у процесі виробництва, але запровадження посерійного контролю ситуативно, або на обмежений термін чи для визначених груп препаратів або для лікарських засобів, які найбільше підробляються впродовж певного періоду - рішення цілком

Необхідннй посерійннй контроль якості ЛЗ в незалежних лабораторіях на етапі оптової торгівлі

Аптека повинна мати право безкоштовно перевірити якість ЛЗ

Уповноважена особа повинна займатися виключно системою забезпечення якості Л3

Медичні працівники мають активно проводити інформаційну роботу шодо фальсифікації ліків

Аптека має бути обладнана терміналом для інформування громадян про ЛЗ

Вагаюсь відповісти

Iнше логічне. Окремо заслуговує на увагу те, що більш ніж 35 \% респондентів вважають за необхідне створити умови, щоб уповноважена особа займалася винятково системою забезпечення якості Л3, без покладання на неї будь-яких інших фрункцій в аптеці (рис. 7).

На заключному етапі дослідження ми опитали фрахівців аптечних закладів на предмет місць найбільш серйозного ризику придбання ФЛЗ. Цікаво, що удвічі більше респондентів (40,27 \% проти 21,74 \%) вважають, що ризик придбати фральсисіковані ліки вищий у невеликих аптечних закладах або аптеках фрізичних осіб-підприємців, ніж в аптеках великих аптечних мереж (рис. 8). Втім мав місце досить високий відсоток тих, хто не визначився з відповіддю - 32,49 \%.

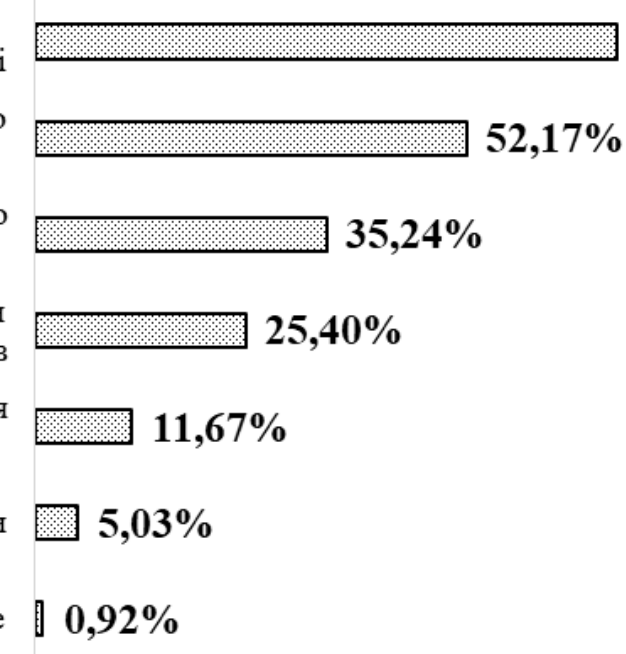

$70,25 \%$

Рис. 7. Додаткові заходи, запровадження яких безпосередньо в аптечних закладах дасть можливість виявляти фральсифріковані ліки та не допускати їхній відпуск.

ISSN 2312-0967. Pharmaceutical review. 2020. № 4 
Організація роботи аптечних підприємств

Organization of pharmaceutical structures' work

У фізичних осіб-підприємців або невеликих аптечних закладах

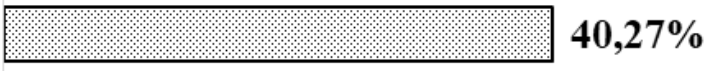

Вагаюсь відповісти

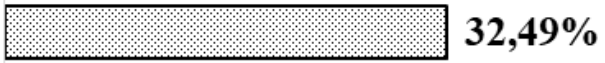

У великих аптечних мережах

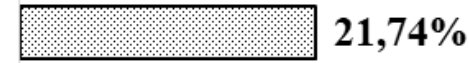

В аптеках та аптечних пунктах, що розташовані в лікувально-профілактичних закладах

Рис. 8. Аптечні заклади, в яких громадяни ризикують з більшою ймовірністю придбати фральсифріковані лікарські засоби.

Висновок. За результатами Всеукраїнського анкетного опитування фрармацевтичних фрахівців аптечних закладів встановлені основні характеристики сучасного стану щодо розповсюдження ФЛЗ та напрямки з удосконалення методів їхнього виявлення: рівень фральсифрікату (від 1 до $10 \%$ ); основні ознаки фральсифрікації та ключові фрактори, які сприяють фральсифрікації ліків; найбільш розповсюджені канали збуту ФЛЗ, перш за все неконтрольована інтернет-торгівля; методи, які слід застосовувати для виявлення Флз під час роздрібної торгівлі, та заходи, які необхідно вживати виробникам ліків для захисту від фральсифрікації своєї продукції, зокрема запровадження додаткових елементів захисту упа-

ковок Л3 від підробок, насамперед маркування 2-d штрих-кодами.

Найважливішим напрямком подальших досліджень стане розробка Національної програми боротьби з фральсифрікацією ліків відповідно до поточних рекомендацій ВОО3 2017 р. «WHO Global Surveillance and Monitoring System for substandard and falsi-fied medical products» [11]. Крім цього, необхідно розробити актуальні практичні рекомендації для фрахівців аптечних закладів щодо виявлення фральсифрікованих препаратів і запобігання їхньому незаконному обігу.

Конфлікт інтересів: відсутній.

Conflicts of interest: authors have no conflict of interest to declare.

\section{EVALUATION OF EFFECTIVENESS OF FIGHT AGAINST FALSIFICATION OF MEDICINES IN UKRAINE: THE VIEW OF PHARMACISTS}

\section{S. O. Lebed ${ }^{1}$, A. S. Nemchenko ${ }^{1}$, M. F. Pasichnyk ${ }^{2}$}

National University of Pharmacy ${ }^{1}$, Kharkiv

Public Association "Pharmaceutical League of Ukraine"2, Kyiv

economica@ukr.net

The aim of the work. To assess the effectiveness of combating drug counterfeiting using a questionnaire survey of specialists from pharmacies in different regions of Ukraine.

Materials and Methods. Scientific publications on the problem of drug counterfeiting, as well as analysis of survey data of specialists of pharmacies in different regions of Ukraine on the problems of combating drug counterfeiting. The research was conducted using the methods of questionnaires, systematization and generalization.

Results and Discussion. According to the results of a questionnaire survey of pharmacy specialists conducted at the national level (13 regions representing the east, west, north, south and center of Ukraine), more than $33 \%$ of respondents answered that the share of counterfeit drugs is from $1 \%$ to $5 \%$, which is in line with WHO data. Among the signs of drug falsification, respondents mostly attributed "Foreign Language Labeling" (44.85\%). Regarding the main sales channels of falsified medicines more than $75 \%$ of respondents named e-commerce. Regarding the methods and measures to be used by manufacturers and pharmacies in the fight against drug counterfeiting, about $75 \%$ of respondents called compliance with the GMP standard, while more than $64 \%$ expect manufacturers to introduce additional protection of drug packaging against counterfeiting, including $44 \%$ - mandatory transition to labeling with 2-d bar codes, as well as more than $78 \%$ of respondents named the purchase of drugs only from suppliers certified for compliance with GDP.

ISSN 2312-0967. Фармацевтичний часопис. 2020. № 4 
Conclusions. In order to create an effective system to combat the spread of counterfeit drugs, it is proposed to create a National Program to Combat Counterfeiting of Medicines, as well as to develop practical recommendations for detecting counterfeit drugs and preventing their illicit trafficking for pharmaceutical professionals.

Key words: drugs; falsification; falsified medicines; pharmacies; pharmaceutical specialists; questionnaires; respondents.

\title{
ОЦЕНКА ЭФФЕКТИВНОСТИ БОРЬБЫ С ФАЛЬСИФИКАЦИЕЙ ЛЕКАРСТВЕННЫХ СРЕДСТВ В УКРАИНЕ: ВЗГЛЯД СПЕЦИАЛИСТОВ АПТЕЧНЫХ УЧРЕЖДЕНИЙ
}

\author{
С. А. Лебедь ${ }^{1}$, А. С. Немченко ${ }^{1}$ М. Ф. Пасичник ${ }^{2}$ \\ Национальный фрармацевтический университет ${ }^{1}$ \\ Общественный союз «Фармацевтическая Лига Украины»² \\ economica@ukr.net
}

\begin{abstract}
Цель работы. Проведение оценки эффективности борьбы с фральсификацией лекарств с использованием анкетного опроса специалистов аптечных учреждений разных регионов Украины.

Материалы и методы. Научные публикации по проблеме фальсификации лекарств, а также анализ данных анкетирования специалистов аптечных учреждений разных регионов Украины по проблемам борьбы с фральсификацией лекарственных средств. Исследования проводились с использованием методов анкетного опроса, систематизации и обобщения.

Результаты и обсуждение. По результатам анкетного опроса специалистов аптечных учреждений, проведенного на национальном уровне (13 областей, представляющих восток, запад, север, юг и центр Украины), более 33 \% опрошенных ответили, что доля фральсифицированных лекарств составляет от 1 до 5 \%, что соответствует данным ВОЗ по объему некачественных и фральсифицированных лекарственных средств в странах с низким и средним уровнем доходов (10,5 \%). К признакам фральсификации лекарственных средств наибольшая часть респондентов (44,85 \%) отнесла «Маркировку на иностранном языке». Относительно основных каналов сбыта фральсифицированных лекарств - более $75 \%$ респондентов назвали интернет-торговлю. Что касается методов и мер, которые должны использоваться производителями и аптеками в борьбе с подделкой лекарств: около 75 \% респондентов назвали соответствие стандарту GMP, в то время как более 64 \% ожидают, что производители введут дополнительную защиту упаковки лекарств от подделки, в том числе 44 \% - обязательный переход на маркировку 2-d штрих-кодами, а также более 78 \% респондентов назвали закупку препаратов только у поставщиков, сертисицированных на соответствие GDP.

Выводы. С целью создания эфффективной системы борьбы с распространением фральсифицированных лекарств предлагается создание Национальной программы борьбы с фральсификацией лекарственных средств, а также разработка практических рекомендаций для фрармацевтических специалистов по выявлению фральсифицированных препаратов и предотвращения их незаконного обращения.
\end{abstract}

Ключевые слова: лекарства; фральсификация; фральсифицированные лекарственные средства; аптечные учреждения; фрармацевтические специалисты; анкетирование; респонденты.

\section{Список бібліографічних посилань}

1. A study on the public health and socioeconomic impact of substandard and falsified medical products. WHO, 2017. URL : https://www.who.int/ publications/i/item/study-on-public-health-socioeconomic-impact-substandard-falsified-medical-products-978-92-4-151343-2

2. Substandard and falsified medical products. WHO. URL : https://www.who.int/health-topics/substandardand-falsified-medical-products\#tab=tab_1

3. Лебедь С. О., Немченко А. С. Експертна оцінка боротьби з фальсифрікацією лікарських засобів в Україні. Фармацевтичний журнал. 2020. Т. 75, № 4. C. $30-38$.

4. Немченко А. С., Лебедь С. О. Аналіз станутапроблем боротьби 3 розповсюдженням фральсифрікованих лікарських засобів. Соціальна фрармація в охороні здоров'я. 2020. Т. 6, № 3. С. 34-40.
5. Тулегенова А. Р., Дильбарханова Ж. Р., Сокуренко И. А. Анализ результатов опроса фрармацевтических работников по проблеме фральсифрикации лекарственных препаратов и их незаконного оборота на фрармацевтическом рынке Республики Казахстан. Управління, економіка та забезпечення якості в фрармації. 2018. № 1 (53). С. 63-71.

6. Каштанова О. А. Научное обоснование оптимизации аудита процессов хранения лекарственных средств на региональном уровне (на примере Астраханской области) : дис. ... канд. фрармац. наук : 14.04.03. Курск, 2013. 230 с.

7. Alwon B. M. Developing a national strategy for combating counterfeit medicines: PhD Thesis. School of Pharmacy University of East Anglia. 2015, 366 p. URL : https://ueaeprints.uea.ac.uk/id/eprint/59256/1/ Bassam_Alwon-PhD_Thesis.pdf.

ISSN 2312-0967. Pharmaceutical review. 2020. № 4 
8. Serialization and verification of medicinal products $-\mathrm{a}$ pilot study among pharmacists in Bulgaria. N. Nedelkov, E. Yordanov, E. Hristov et al. Acta Medica Bulgarica. 2019. Vol. XLVI, No. 3. P. 18-22.

9. Khokhlova N. A., Demyanenko V. G., Breusova S. V. Study for the reasons of counterfeit drugs incoming into pharmacies of Kharkov city. Actual questions of development of new drugs: abstr. XX intern. scient. and pract. conf., Kharkiv, April 22-23, 2014. Kharkiv, 2014. P. 324.

10. До відома споживачів лікарських засобів. Державна служба України 3 лікарських засобів та контролю за наркотиками. URL: https://www. dls.gov.ua/dicls_news/\%D0\%B4\%D0\%BE-\%D0 $\%$ B2\%D1\%96\%D0\%B4\%D0\%BE\%D0\%BC\%D0 \%B 0-\%D1\%81\%D0\%BF\%D0\%BE\%D0\%B6\%D 0\%B8\%D0\%B2\%D0\%B0\%D1\%87\%D1\%96\%D0 \%B2-\%D0\%BB\%D1\%96\%D0\%BA\%D0\%B0\%D1\%80\%D1\%81\%D1\%8C\%D0\%BA\%D0\%B8\%D1\%85\%D0\%B7\%D0\%B0\%D1\%81\%D0\%BE-2/

11. WHO Global Surveillance and Monitoring System for substandard and falsified medical products. WHO, 2017. URL : https://uww.who.int/publications//item/978-92-4-151342-5.

\section{References}

1. A study on the public health and socioeconomic impact of substandard and falsified medical products. WHO, 2017. Available from: https://www.who.int/ publications/i/item/study-on-public-health-socioeconomic-impact-substandard-falsified-medical-products-978-92-4-151343-2

2. Substandard and falsified medical products. WHO Available from: https://www.who.int/health-topics/substandard-and-falsified-medical-products $\#$ tab=tab_1

3. Lebed SO, Nemchenko AS. [Expert assessment of the fight against drug falsification in Ukraine]. Farm zhurn. 2020;75(4): 30-8. Ukrainian.

4. Nemchenko AS, Lebed SO. [Analysis of the state and problems of combating the spread of counterfeit medicines]. Sots farm v okhor zdor. 2020;6(3): 34-40. Ukrainian.

5. Tulehenova AR, Dylbarkhanova ZhR, Sokurenko IA [Analysis of the results of the survey of pharmaceutical workers on the problem of falsification of drugs and their illicit trafficking in the pharmaceutical market of the Republic of Kazakhstan]. Upravl, ekon ta zapez yak v farm. 2018;1(53): 63-71. Russian.

6. Kashtanova OA. Scientific substantiation of optimization of audit of processes of storage of medicines at the regional level (on an example of the Astrakhan area) [Thesis]. Kursk; 2013. 230 p. Russian.

7. Alwon BM. Developing a national strategy for combating counterfeit medicines : PhD Thesis. School of Phar-

macy University of East Anglia. 2015, 366 p. Available from: https://ueaeprints.uea.ac.uk/id/eprint/59256/1/ Bassam_Alwon-PhD_Thesis.pdf.

8. Nedelkov N, Yordanov E, Hristov E, Petkova V, Ognianov $\mathrm{S}$, Andreevska $\mathrm{K}$ et al. Serialization and verification of medicinal products - a pilot study among pharmacists in Bulgaria. Acta Med. Bulg. 2019; XL VI (3):18-22.

9. Khokhlova NA, Demyanenko VG, Breusova SV. Study for the reasons of counterfeit drugs incoming into pharmacies of Kharkov city. Actual questions of development of new drugs : abstr. XX intern. scient. and pract. conf.; 2014 Apr 22-23; Kharkiv. Kharkiv: NUPh; 2014. p. 324.

10. Attention to consumers of medicines. State Service of Ukraine for Medicines and Drug Control. Available from: https://www.dls.gov.ua/dicls_news/\%D0\%B4\%D0\%BE-\%D0\%B2\%D1\% 96\%D0\%B 4\%D0\%BE\%D0\%BC\%D0\%B0-\%D1 \% 81\%D 0\%BF\%D 0\%BE\%D0\%B6\%D0\%B8\% D0\%B 2\%D0\%B0\%D1\%87\%D1\%96\%D0\%B2\%D0\%BB\%D1\%96\%D0\%BA\%D0\%B0\%D1\%80\%D1\%81\%D1\%8C\%D0\%BA\%D0\%B8\%D1\%85\%D0\%B7\%D0\%B0\%D1\%81\%D0\%BE-2/. Ukrainian.

11. WHO Global Surveillance and Monitoring System for substandard and falsified medical products. WHO, 2017. Available from: https://www.who.int/ publications/i/item/978-92-4-151342-5

\section{Відомості про авторів}

Лебедь С. О. - аспірант, Заслужений працівник фрармації України, Національний фрармацевтичний університет, м. Харків, Україна. E-mail: s.lebed2016@gmail.com, ORCID 0000-0002-4368-2123.

Немченко А. С. - д. фрармац. наук, професор, завідувач кафедри організації та економіки фрармації, Заслужений діяч науки і техніки України, Національний фармацевтичний університет, Харків, Україна. E-mail: economica@ukr. net, ORCID 0000-0003-1601-8881.

Пасічник М. Ф. - канд. фрармац. наук, президент Громадської спілки «Фармацевтична Ліга України», Київ, Україна. E-mail: office@pharmliga.com.ua, ORCID 0000-0002-6346-9442.

\section{Information about the authors}

Lebed S. O. - PhD-student, Honored Worker of Pharmacy of Ukraine, National University of Pharmacy, Kharkiv, Ukraine, E-mail: s.lebed2016@gmail.com, ORCID 0000-0002-4368-2123.

Nemchenko A. S. - DSc (Pharmacy), Professor Honored Worker of Science and Technology of Ukraine, Head of the Department of Organization and Economics of Pharmacy, National University of Pharmacy, Kharkiv, Ukraine. E-mail: economica@ukr.net, ORCID 0000-0003-1601-8881.

Pasichnyk M. F. - PhD (Pharmacy), President of the Public Union "Pharmaceutical League of Ukraine", Kyiv, Ukraine. E-mail: office@pharmliga.com.ua, ORCID 0000-0002-6346-9442.

ISSN 2312-0967. Фармацевтичний часопис. 2020. № 4 